\title{
Geophysical analysis of transverse ridges and internal structure at Lone Peak Rock Glacier, Big Sky, Montana, USA
}

\author{
Caitlyn FLORENTINE, ${ }^{1}$ Mark SKIDMORE, ${ }^{1}$ Marvin SPEECE, ${ }^{2}$ Curtis LINK, ${ }^{2}$ \\ Colin A. SHAW ${ }^{1}$ \\ ${ }^{1}$ Department of Earth Sciences, Montana State University, Bozeman, MT, USA \\ E-mail: caitlyn.florentine@gmail.com \\ ${ }^{2}$ Department of Geophysical Engineering, Montana Tech, University of Montana, Butte, MT, USA
}

\begin{abstract}
Rock glaciers are periglacial alpine landforms that are found in many locations worldwide. Whereas well-developed models of deformation are established for traditional alpine glaciers, rock glacier deformation is poorly understood. Geophysical data from Lone Peak Rock Glacier (LPRG), southwest Montana, USA, are paired with lidar bare-earth $1 \mathrm{~m}$ digital elevation model (DEM) analysis to explore potential genetic relationships between internal composition, structure and regularly spaced arcuate transverse ridges expressed at the rock glacier surface. The internal composition of LPRG is heterogeneous, with frozen debris and clean ice overlain by an unconsolidated talus mantle. Upslopedipping, clearly distinguished reflectors in the ground-penetrating radar (GPR) longitudinal survey at LPRG correspond to transverse ridges. The spacing and slope of individual features at the surface and in the subsurface were measured and compared and are found to be similar. The structures observed at LPRG and other rock glaciers are similar to structures detected in glaciotectonically altered sediment, ice-cored moraines and other rock glacier settings. This finding suggests that transverse ridges on rock glaciers may be used as geomorphic indicators of internal deformation. This study contributes to the body of research on the application of GPR to rock glaciers, and is the first to directly pair and analyze individual surface topographic features with internal structures.
\end{abstract}

KEYWORDS: glacial geomorphology, ground-penetrating radar, mountain glaciers, permafrost

\section{INTRODUCTION}

Rock glaciers are talus-mantled periglacial features generally located in continental mountain ranges, though active rock glaciers have been observed worldwide at a broad range of elevations in both coastal and continental mountain ranges (Barsch, 1996). Rock glaciers flow due to the presence of internal ice yet, unlike traditional alpine glaciers, no predictive explanation of rock glacier deformation exists. The mechanical driver and resulting structural style of deformation is uncertain. Uncertainty is primarily due to rheological complexity as rock glaciers consist of rock and ice in unknown heterogeneous structure, which varies from landform to landform. Findings on particular flow properties measured and modeled within rock glaciers are widely variable due to this ever-uncertain ratio of ice versus frozen debris (Wagner, 1992; Whalley and Azizi, 2003), though related studies of debris-laden ice may provide approximations (Iverson and others, 2003; Lawson and Elliott, 2003; Ikeda and others, 2008). Rock glaciers move at low flow velocities $\left(\mathrm{cm} \mathrm{a}^{-1}\right)$, in contrast to traditional alpine glaciers, which are primarily fed by snow, consist predominantly of ice and move at higher flow velocities $\left(\mathrm{m} \mathrm{a}^{-1}\right)$ (Hamilton and Whalley, 1995; Whalley and Azizi, 2003).

Rock glaciers exhibit some common geomorphic surface features, including arcuate, regularly spaced transverse ridges on the talus surface (Barsch, 1996). No definitive explanation of transverse ridge formation exists, though there are multiple working hypotheses as to their genesis (e.g. Wahrhaftig and Cox, 1959; Potter, 1972; Haeberli, 1985; Olyphant, 1987; White, 1987; Loewenherz and others, 1989; Barsch, 1996; Kääb and others, 1998; Fukui and others, 2008; Degenhardt, 2009; Shean and Marchant,
2010). Transverse ridges have been described as the result of exogenous processes (e.g. thermal alteration or change in debris input) (Barsch, 1996) and/or endogenous processes (e.g. thrust faulting or buckling due to rheological heterogeneity) (White, 1971; Loewenherz and others, 1989; Arenson and others, 2002; Fukui and others, 2007). Some researchers invoke specific endogenous processes and suggest that transverse ridges are a surface expression of thrust shearing in localized high-strain zones (White, 1971; Barsch, 1996; Arenson and others, 2002; Kääb and Weber, 2004). Upslope-dipping subsurface structures have been detected in previous ground-penetrating radar (GPR) surveys (Berthling and others, 2000; Fukui and others 2008), and in a few cases have been individually linked to surface ridges (Shean and Marchant, 2010; Monnier and others 2011). These studies do not investigate the spatial relationship of slope and spacing between transverse ridges and upslopedipping subsurface structures.

Hypotheses relating transverse ridges to thrusting or internal deformation within a rock glacier ice body do not necessarily suggest transport of debris from the glacier bed to the surface (Fukui and others, 2008; Moore and others, 2010). Internal deformation may include a complex suite of deformation styles within a heterogeneous mix of material, i.e. perhaps stress within the rock/ice body does not result in localized deformation throughout but manifests as ductile deformation (folding) at depth, while thrusting is limited to the near-surface. Such near-surface thrusting may occur along spatial patterns similar to those of folding/rotating planar surfaces at depth, and hence result in surface transverse ridges: such a hypothesis matches transverse ridges to internal deformational features without invoking 
thrusting throughout the ice body or transport via thrusting of basal sediment to the surface.

Geophysical methods, including GPR and seismic refraction surveys, as well as coring and borehole techniques have provided subsurface information on the composition and internal structure of a few selected rock glaciers (Steig and others, 1998; Berthling and others, 2000; Isaksen and others, 2000; Fukui and others, 2007, 2008; Hausmann and others, 2007; Monnier and others, 2011). The application of GPR to rock glacier and other frozen ground surveying is effective and well described by Degenhardt and Giardino (2003) and Woodward and Burke (2007). These GPR data suggest that the internal ice body of a rock glacier is typically buried beneath meters to decimeters of rock debris (Elconin and LaChapelle, 1997), and is composed of interstitial ice between debris (Haeberli and others, 2006) or as pure ice (Potter, 1972). The origin of ice may be sedimentary (seasonal snow accumulation, avalanching, rockfall), periglacial (refreezing of meltwater seeping into pre-existing sediments) (Guglielmin and others, 2004) or glacial (buried glacier ice) (Whalley and Azizi, 2003). In sum, ice within any one given rock glacier may be glacial, periglacial or some combination of both in origin. Polygenetic ice and/or the presence of rock debris in varying abundance yields compositional and structural complexity (Haeberli and others, 2006).

The objectives of this study are to: (1) relate surface morphology, particularly transverse ridges, to internal structure and composition of a rock glacier in the Northern Rockies, USA; and (2) evaluate this relationship as evidence that rock glacier surface topography may be a direct geomorphic indicator of internal deformation.

\section{BACKGROUND}

\section{Northern Rocky Mountains}

The US Northern Rocky Mountains (NRM) were extensively glaciated during the Pleistocene (Locke, 1990). Although only a few remnant alpine glaciers remain, modern periglacial features are widespread at higher elevations and include rock glaciers (e.g. Johnson and others, 2007; Seligman, 2009). Debris-mantled ice within rock glaciers has the potential to preserve climate records (e.g. Clark and others, 1994; Konrad and others, 1999) and cryo-ecologic microbial communities (e.g. Florentine, 2011). In southwest Montana, rock glaciers are found above $2000 \mathrm{~m}$ a.s.l., where the climate is semi-arid and cold; the mean annual precipitation ranges from 25 to $183 \mathrm{~cm}$ and the annual mean of daily minimum temperature varies spatially from $-13^{\circ} \mathrm{C}$ to $1^{\circ} \mathrm{C}$ (PRISM Group, http://www.prism.oregonstate. edu). Regional distribution of rock glaciers was assessed via Google Earth. The geomorphic identification of rock glaciers was defined by the following landform attributes: talusmantled, connected to a talus slope, having steep margins and above treeline. The presence of transverse ridges on the rock glacier was also noted; however, landforms with bulbous or non-regular ridges were not included in this group. Rock glaciers are located in previously glaciated terrain and are primarily northeast-facing (average $18^{\circ}$ ) (Florentine, 2011). Transverse ridge morphology is displayed in approximately one-third (125/383) of rock glaciers in the Beartooth Plateau, Absaroka, Gallatin and Madison ranges (Figs 1a and 2) (Florentine, 2011), and it is recognized that this may include both active and inactive landforms.

\section{Lone Peak Rock Glacier}

Lone Peak, located in the Madison Range of southwestern Montana (Fig. 1a), is representative of the topographic and geomorphic setting of the region's rock glaciers. Its representative character was determined after comparison with 383 rock glaciers inventoried in the region (Florentine, 2011). Lone Peak Rock Glacier (LPRG) (Fig. 1b) is located on the property of Big Sky Resort and situated in a northeast-facing cirque basin. LPRG is $1.7 \mathrm{~km}$ in length, $\sim 60-150 \mathrm{~m}$ wide and ranges from 2600 to 3100 ma.s.l. The cirque headwall consists of Mesozoic sedimentary rocks, predominantly shales, and andesite, and the surface of LPRG is characterized by blocky porphyritic andesite talus, with a small percentage of angular siliceous siltstone talus generally $<20 \mathrm{~cm}$ (Fig. 3a and b). Goolsby (1972) divided LPRG into segments based on morphologic and stability assessments. The most active, uppermost segment has a slope of $\sim 10^{\circ}$, a $\sim 40^{\circ}$ frontal scarp, and a series of arcuate transverse ridges separated by shallow ( $2-3 \mathrm{~m}$ ) furrows (Fig. 1c and d). The transverse ridges are convex toward the terminus of the active segment, and tend to be steeper toward the rock glacier head and shallower toward the terminus (Fig. 1c). Big Sky Resort constructed a ski tram base station in 1995 on a lower separate segment of the glacier just below the toe of the most active segment (Fig. 1c). During construction a borehole was drilled into the rock glacier and this revealed that the internal composition of LPRG was composed of a heterogeneous mixture of clean ice and frozen debris (Florentine, 2011).

\section{METHODS}

Lidar digital elevation model (DEM) data for the Lone Peak (west fork of the Gallatin River) watershed were downloaded from the US National Center for Airborne Laser Mapping website (http://calm.geo.berkeley.edu/ncalm/ddc.html). These $1 \mathrm{~m}$ resolution filtered (bare-earth) DEM data were analyzed using ArcGIS software to generate topographic profiles, contoured topographic maps and slope maps at LPRG.

The ski resort has accurately monitored downslope movement of the tram station via GPS since its construction in 1995; therefore, limited velocity data are available for the last 17 years. Excavations on the rock glacier surface took place in August 2009 with a backhoe (Fig. 3b), and ice blocks were recovered with a chainsaw (Fig. 3c).

GPS data for geophysical transects were collected using a hemisphere GPS device, which has a horizontal accuracy of $0.6 \mathrm{~m}$ when using the WAAS (wide area augmentation system) correction. Seismic refraction surveys were performed along transverse and longitudinal transects of the rock glacier in August 2009 (Fig. 1c). Geophones were positioned at $1 \mathrm{~m}$ intervals along an $87 \mathrm{~m}$ transverse transect and a $197 \mathrm{~m}$ longitudinal transect. A sledgehammer seismic source was used at $5 \mathrm{~m}$ shot stations, stacking the data eight times at each location. The data were recorded using a Geometrics Geode recording system with $0.125 \mathrm{~ms}$ sampling period and 4000 samples per trace. The shot records were processed by picking first arrival times, and then analyzed using refraction tomography and layered solutions with Rayfract ${ }^{\mathbb{R}}$ software, Intelligent Resources Inc.

GPR data were collected at LPRG in February 2010 along transverse and longitudinal transects similar to those for the seismic refraction measurements (Fig. 1c). A MALA Geoscience Ramac GPR system was used for data acquisition, 


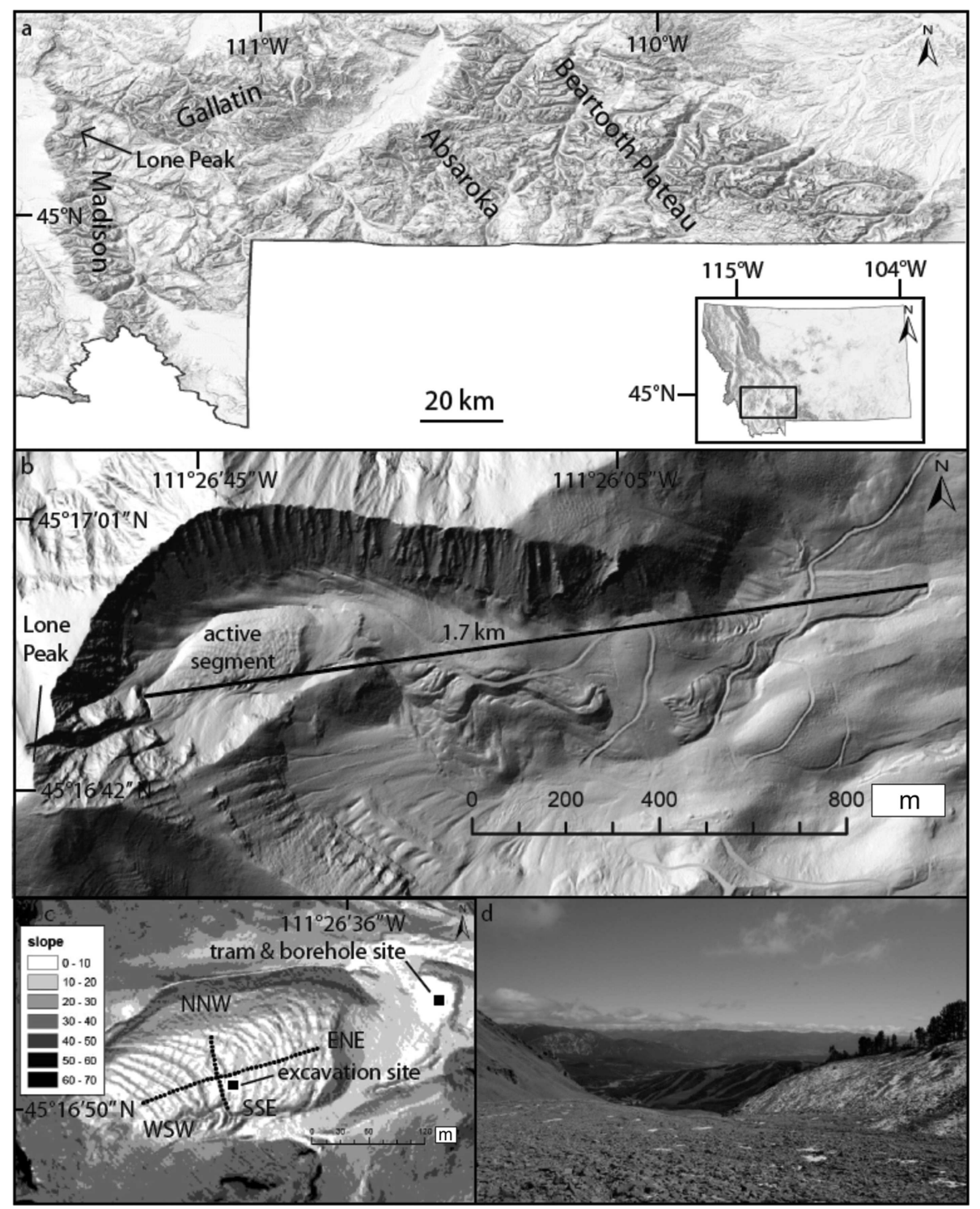

Fig. 1. (a) Study area in southwest Montana; arrow indicates the site of LPRG. (b) Hillshade lidar bare-earth $1 \mathrm{~m}$ DEM featuring northeast cirque of Lone Peak. Tram not visible due to bare-earth lidar. LPRG extends $1.7 \mathrm{~km}$ valleyward; the uppermost active segment is the focus of this study. (c) Uppermost active segment of LPRG illustrated by slope-characterized lidar data with geophysical transects. Longitudinal transect west-southwest to east-northeast; transverse transect south-southeast to north-northwest. The base station of Big Sky Resort tram and excavation site are indicated. Slope scale in degrees. (d) Transverse ridges on LPRG surface. Ridges trend across the field of view. View is toward rock glacier toe.

and RadExplorer ${ }^{\circledR}$ software (DECO Geophysical Ltd) was used to process data. All profiles were repeated using 25, 50 and $100 \mathrm{MHz}$ antennas. Lower-frequency data (25 and $50 \mathrm{MHz}$ ) were collected in an attempt to detect contact between rock glacier and bedrock (see supplementary material at http://igsoc.org/hyperlink/13j160/appendix1.pdf). Data collected for these frequencies reached depths of $\sim 60$ and $\sim 40 \mathrm{~m}$, respectively, yet bedrock still was not detected. Therefore, results of the $100 \mathrm{MHz}$ data are analyzed for rock glacier internal structure as they yield the highest resolution. An average radar velocity of $0.157 \pm 0.012 \mathrm{~m} \mathrm{~ns}^{-1}$ was used to convert from time to depth. This velocity was determined by fitting hyperbolas to weak diffractions in the data, and is similar to other ice-cored rock glaciers (Isaksen and others, 2000; Monnier and others, 2011). Other field-recording parameters and GPR data-processing details are presented as supplementary material at http://igsoc.org/hyperlink/13j160/ appendix2.pdf. Using the Rayleigh quarter-wavelength vertical resolution criteria and our calculated velocity of $0.157 \mathrm{~m} \mathrm{~ns}^{-1}$ we estimate a vertical resolution of $0.4 \mathrm{~m}$ for the $100 \mathrm{MHz}$ GPR data.

Individual features representing transverse ridges (surface features) and upslope-dipping reflectors (subsurface features) were identified on both lidar DEM- and GPRgenerated data. Seismic refraction data were not included in this phase of analysis; seismic data were utilized to identify the depth of the contact between unconsolidated debris and frozen substrate. Slope and distance measurements on lidar DEM surface topographic profiles and GPR radargrams were conducted by overlaying these images with a grid. Distance of rise over run of each feature was measured to the nearest $1 \mathrm{~m}$, and is reported as a ratio for percent grade (slope). Distance between features was likewise measured to the nearest $1 \mathrm{~m}$ (spacing). Data for slope and spacing are reported with a resolution of $1 \%$ and $1 \mathrm{~m}$, respectively. 


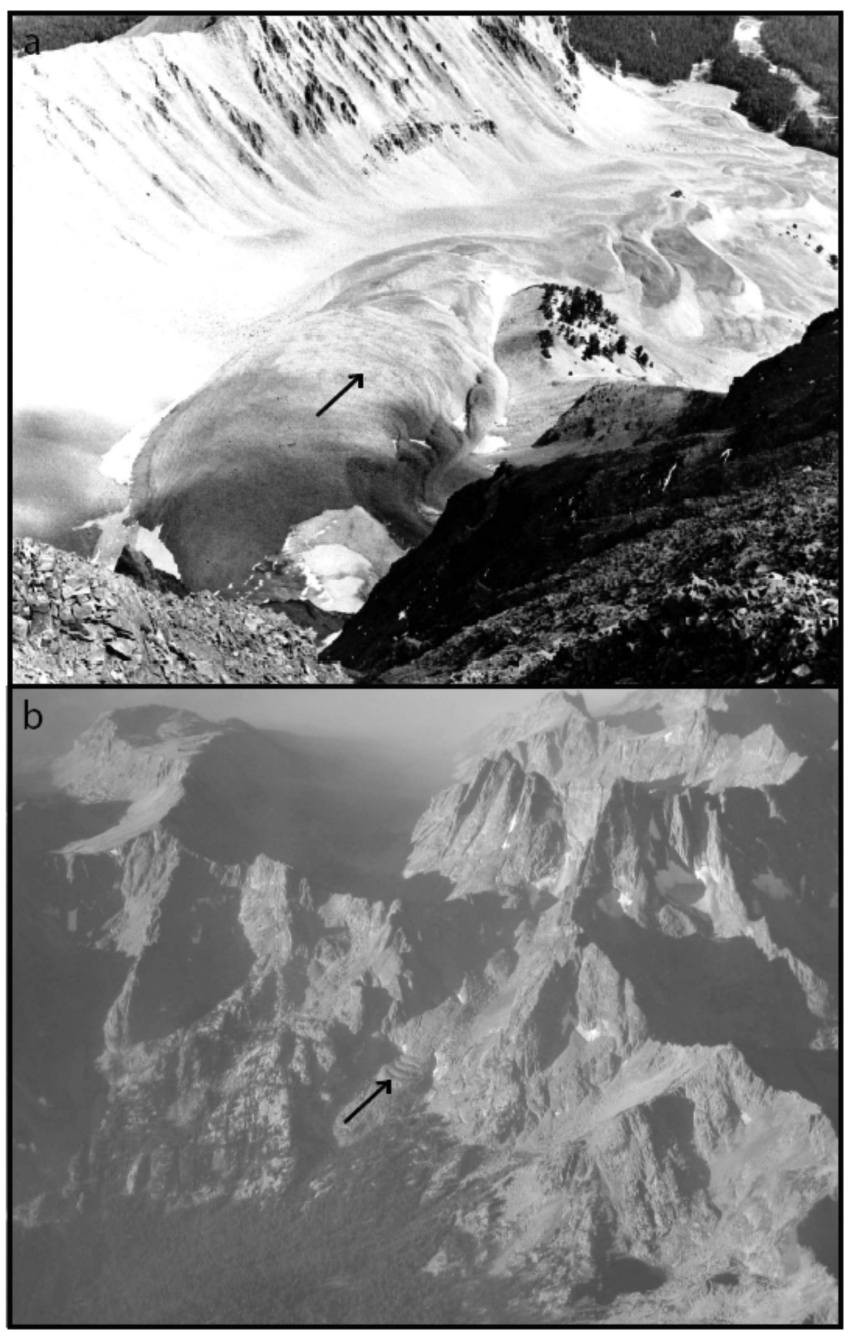

Fig. 2. Two rock glaciers in southwest Montana. Arrows indicate regularly spaced transverse ridges at each site. (a) LPRG prior to tram construction. Aspect is northeast. (b) Absaroka Mountains. Photograph credits: (a) Taylor Middleton and (b) Christina Carr.

\section{GEOPHYSICAL AND LIDAR-GENERATED RESULTS}

Raw data for the seismic refraction and GPR data are presented in Figure 4 for longitudinal and transverse profiles. The uncertainty associated with the GPS position data $(0.6 \mathrm{~m})$ is an order of magnitude lower than the spacing of the surface and subsurface features.

\section{Landform analysis}

Measurements collected via GPS monitoring of the base of the tram at LPRG indicate downslope movement of $\sim 20 \mathrm{~cm} \mathrm{a}^{-1}$ (Big Sky Resort, unpublished data). These velocity data are for a different segment of the rock glacier, which is thought to be less active than the active uppermost segment where transverse ridges are located. We therefore interpret this velocity as a minimum for the active segment.

Transverse ridges on the active segment at LPRG are well illustrated when characterized by slope angle (Fig. 1c). These transverse ridges will be referred to as surface features for subsequent comparison with subsurface features. The longitudinal profile of geophysical data, running west-southwest to east-northeast from the head of the rock glacier toward the toe, begins at one transverse ridge (feature 1 ) and cuts across nine prominent ridges (features 2-10) and four less prominent ridges (features 11-14) (Fig. 5). Prominent ridges are asymmetric, with steep slopes toward the headwall, and strike northwest to southeast, or roughly perpendicular to the longitudinal profile. Less prominent ridges are also asymmetric, though their upslope aspect may be distinguished by a flattening in slope as opposed to an actual reversal of slope from the ridge above. Hence two less prominent ridges (features 1 and 13) were measured with upslope faces (negative slope). Ridges are visible and roughly regular in plan-view maps of LPRG (Fig. 1c); however, in cross section the regularity of ridges is less apparent (Fig. 4a). The nine prominent transverse ridges (features $2-10$ ) are separated by $7-16 \mathrm{~m}$ (mean value $11 \pm 3 \mathrm{~m}, n=9$ ) and have upslope aspect slopes of $5-20 \%$ (mean value $11 \pm 5 \%, n=9$ ) (Fig. 5a).

\section{Depth of talus mantle: excavation and seismic refraction results}

Excavations in the center of the uppermost segment of the rock glacier reveal a heterogeneous mixture of clean ice and frozen debris, specifically $\sim 3 \mathrm{~m}$ of relatively unsorted angular talus and colluvium underlain by $\sim 20 \mathrm{~cm}$ of clean ice, underlain by frozen debris of an unknown depth and thickness (Fig. 3c and d). The $\sim 20 \mathrm{~cm}$ clean-ice layer at $\sim 3 \mathrm{~m}$ depth yielded samples that were bubble-rich and contained an amber ice band $10 \mathrm{~cm}$ thick and $0.1 \%$ debris by weight (Fig. 3c) (Florentine, 2011).

Seismic refraction surveys from transverse and longitudinal profiles verified the presence of a frozen substrate at depth, buried under unconsolidated debris, throughout the profiles (Fig. 4a and b). Refraction velocities were determined using a plus-minus method. Refraction velocities were relatively consistent, with $400 \mathrm{~m} \mathrm{~s}^{-1}$ detected for the upper layer and $3500 \mathrm{~m} \mathrm{~s}^{-1}$ for the lower layer at a depth of $2-3 \mathrm{~m}$. The velocity of the lower layer $\left(3500 \mathrm{~m} \mathrm{~s}^{-1}\right)$ is slightly less than other observed refraction velocities for ice (Hausmann and others, 2007; Shean and Marchant, 2010) and is consistent for velocities observed for rock glaciers (Potter and others, 1998; Leopold and others, 2008).

\section{Internal structure: $100 \mathrm{MHz}$ GPR results}

$100 \mathrm{MHz}$ GPR data of the longitudinal profile of LPRG demonstrate upslope-dipping reflectors, which are evident to a depth of $\sim 25 \mathrm{~m}$ (Fig. 4c). Nine of these reflectors, hereafter referred to as subsurface features, are prominent and particularly distinctive (features 2-10). These reflectors slope toward the rock glacier headwall with varying steepness ranging from $29 \%$ to $54 \%$ (mean value $42 \pm 10 \%$, $n=9$ ), and the nine prominent reflectors are spaced at intervals ranging from 8 to $23 \mathrm{~m}$ (mean value $12 \pm 5 \mathrm{~m}, n=9$ ) (Fig. 5c).

\section{TRANSVERSE RIDGE DEVELOPMENT AND SIGNIFICANCE}

\section{Transverse ridge formation models}

Transverse ridges are common geomorphic features of rock glaciers and thus apparently record some prevalent process of debris accumulation (exogenous model) or ice flow (endogenous model). Transverse ridges are present at LPRG and other rock glaciers in the Northern Rockies of southwest Montana (33\%, $n=383$; Florentine, 2011) as well as in many locations worldwide. Two competing models have been advanced for the origin of transverse ridges. Exogenous models call on quasi-periodic temporal fluctuations in supply of debris to the glacier surface to account for the 


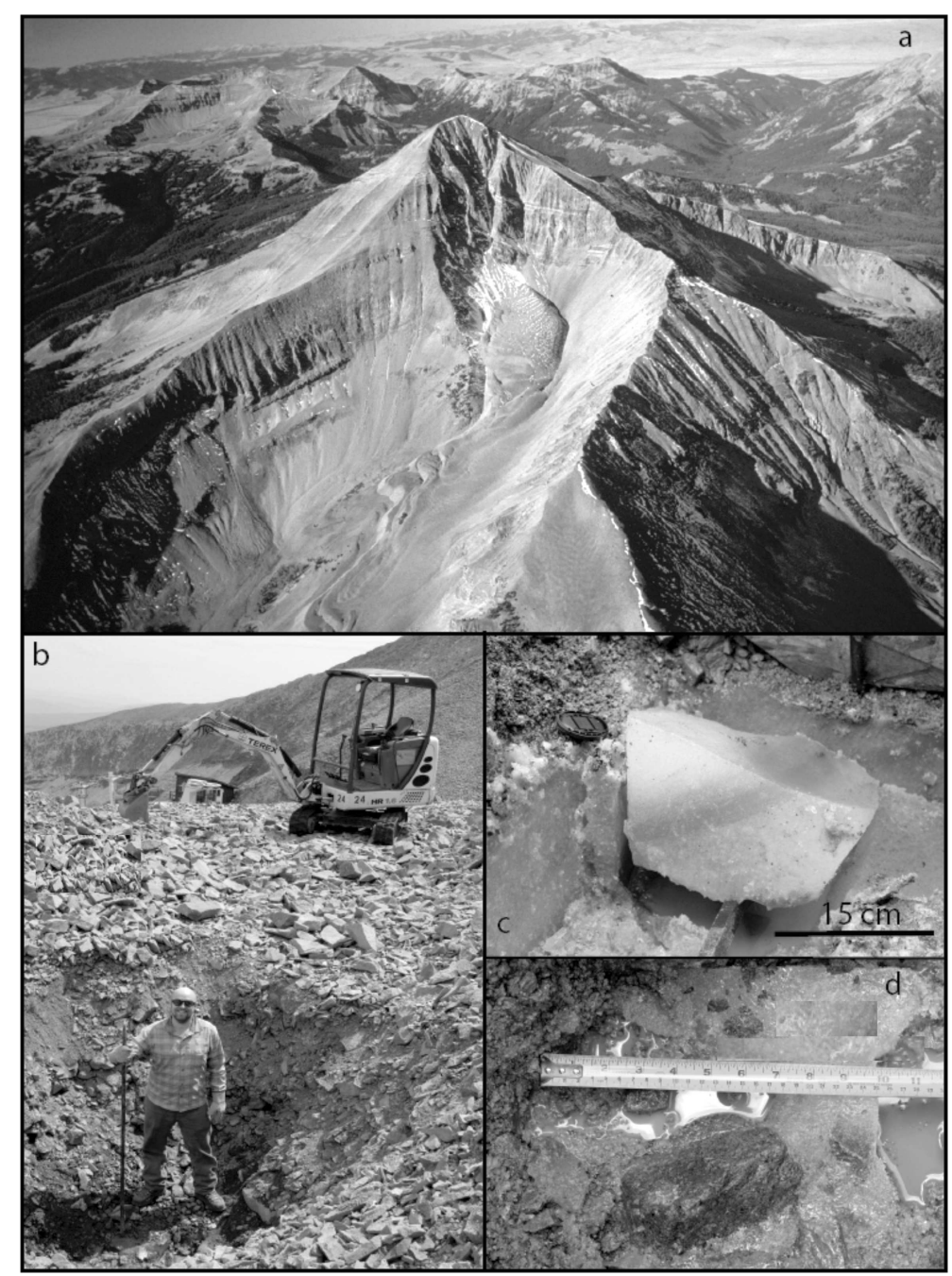

Fig. 3. (a) Aerial view of LPRG taken during summer in the 1980s. (Photograph credit: Dave Lageson.) (b) Excavation pit $\sim 2 \mathrm{~m}$ deep. Excavated material consisted of unconsolidated talus. (c) Clean bubble-rich ice encountered directly beneath unconsolidated talus. Upslope-dipping amber ice band illustrated. (d) Frozen debris encountered directly beneath clean ice.

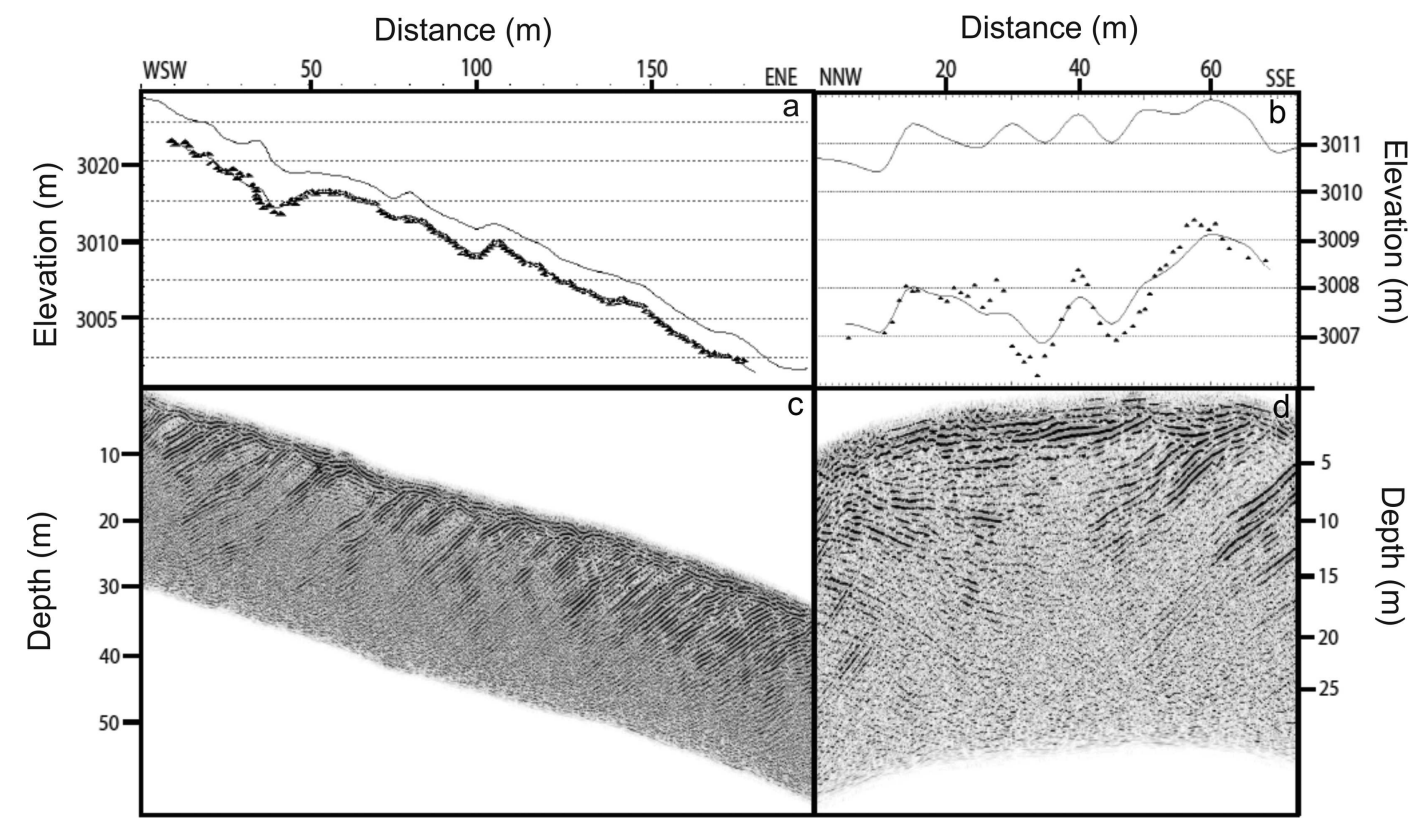

Fig. 4. (a) Longitudinal and (b) transverse seismic refraction results. Top curve is surface elevation. Triangles represent discrete elevations of V1/V2 transition along the profile where V1 is unconsolidated talus velocity and V2 is frozen substrate velocity. Smoothed elevations represented by the solid line. (c) Longitudinal and (d) transverse $100 \mathrm{MHz}$ GPR results. 


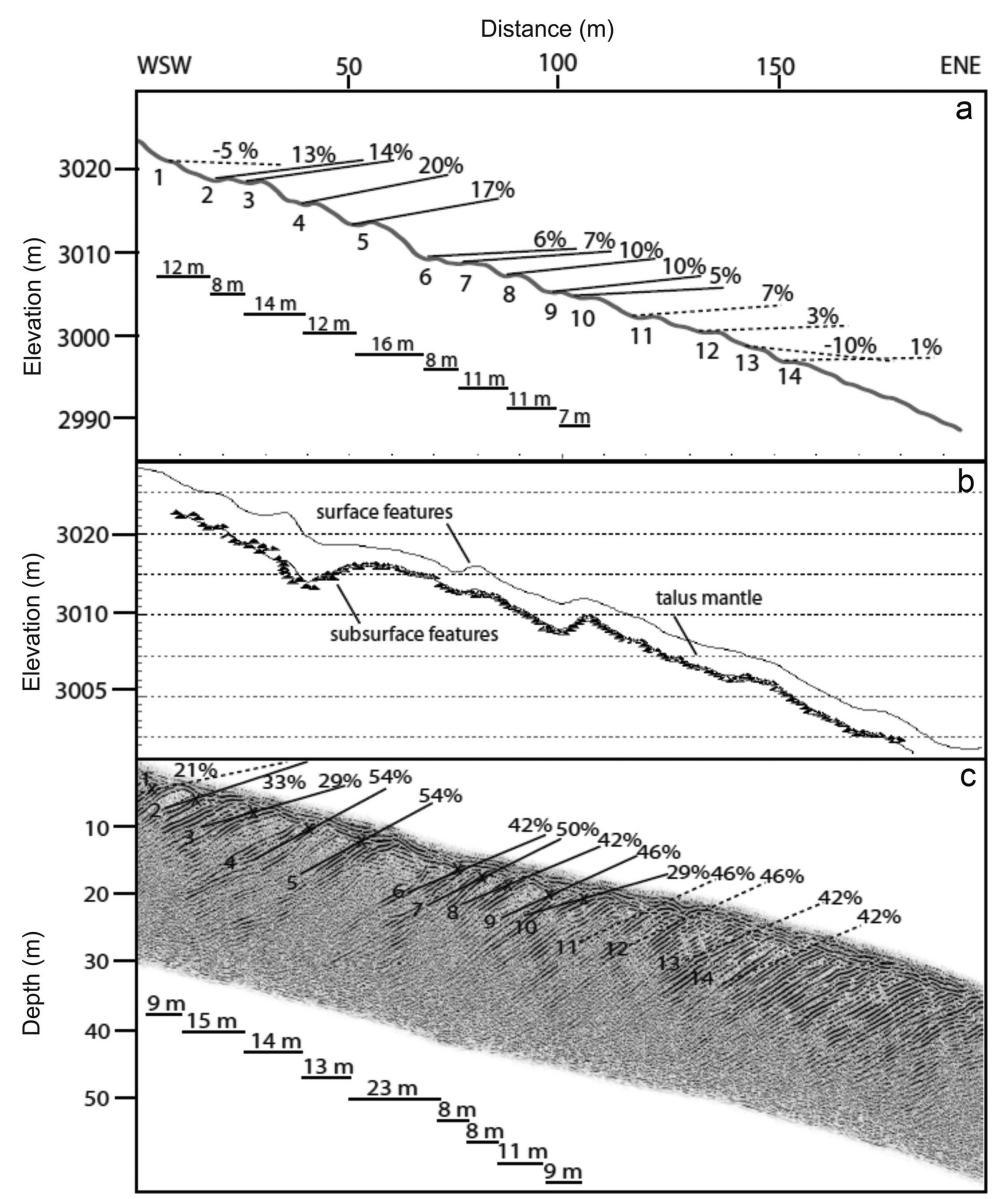

Fig. 5. (a) Longitudinal surface elevation data with individual ridges (i.e. surface features) labeled 1-14. Lines illustrate upslope dip of each ridge. Ridges illustrated with dotted lines $(1,11-14)$ are not included in slope and distance statistics. Slopes and spacing of each feature are noted. (b) Longitudinal seismic refraction data illustrating surface and subsurface features. (c) Longitudinal GPR data with individual subsurface features labeled 1-14 to match surface features. Slopes and spacing of each feature are noted.

quasi-periodic spatial pattern of transverse ridges (Barsch, 1996). Such models make several predictions for the morphology and spacing of topography on the rock glacier surface: (1) ridge spacing $(d)$ should be related to glacier surface velocity $(v)$ and the frequency of the debris supply cycle $(f)$ by the simple functional relationship $d=v f$, although both $v$ and $f$ may vary with time; and (2) debris topography is unlikely to be in-phase with the underlying debris/ice contact.

Endogenous models relate transverse ridge topography to the internal dynamics of glacial flow (e.g. White, 1971; Loewenherz and others, 1989; Arenson and others, 2002; Fukui and others, 2007). In endogenous models, ridges and troughs correspond to spatial variations in glacial flow vectors, resulting in localized surface uplift. These models include internal thrust faulting (Wahrhaftig and Cox, 1959; White, 1987). Such models predict: (1) transverse ridge topography that is likely to be in-phase with the debris/ice contact; and (2) ridge location and spacing that correlate with the location and spacing of structures (e.g. shear zones) in the body of the glacier. Both these predictions are supported by geophysical data from LPRG.

\section{Periodicity of surface features and the exogenous model}

An exogenous origin of transverse ridges at LPRG, at least similar to annual ogives, seems unlikely given that exogenous model prediction of the relationship between landform velocity $(v)$, ridge spacing $(d)$ and debris supply cycle $(f)$ does not match data from LPRG. Annual velocity data are available for the bottom tram station, and represent an approximate velocity $\left(v \sim 0.2 \mathrm{~m} \mathrm{a}^{-1}\right)$ for the active uppermost segment of LPRG where transverse ridges are well developed. Transverse ridge spacing has a mean value of $11 \pm 3 \mathrm{~m}(n=9)$. Considering an annual frequency of debris supply cycle $(f=1$ year), $d=v f$ is not true, i.e. annual deposition of debris at the headwall will not result in transverse ridges at the spacing observed at LPRG. The second model prediction for exogenous formation of transverse ridges is that surface debris topography and subsurface debris/ice contact topography are unlikely to be in-phase. Data from LPRG suggest that these topographic profiles are in-phase, supporting an endogenous process, which predicts a high likelihood of surface and subsurface phasing.

\section{Thrust faulting and the endogenous model}

We interpret subsurface structures detected by $100 \mathrm{MHz}$ GPR data to be thrust faults or shear bands. Analogous GPR signatures at other rock glaciers and in glaciotectonically altered sediment and debris inclusions in glacier ice have been interpreted similarly as thrust planes (Jakobsen and Overgaard, 2002; Woodward and others, 2003; Sadura and others, 2006; Fukui and others, 2008; Monnier and others, 2011). Thrusting occurs as a result of flattening or upslope steepening, such as a rollover, in underlying topography, as 


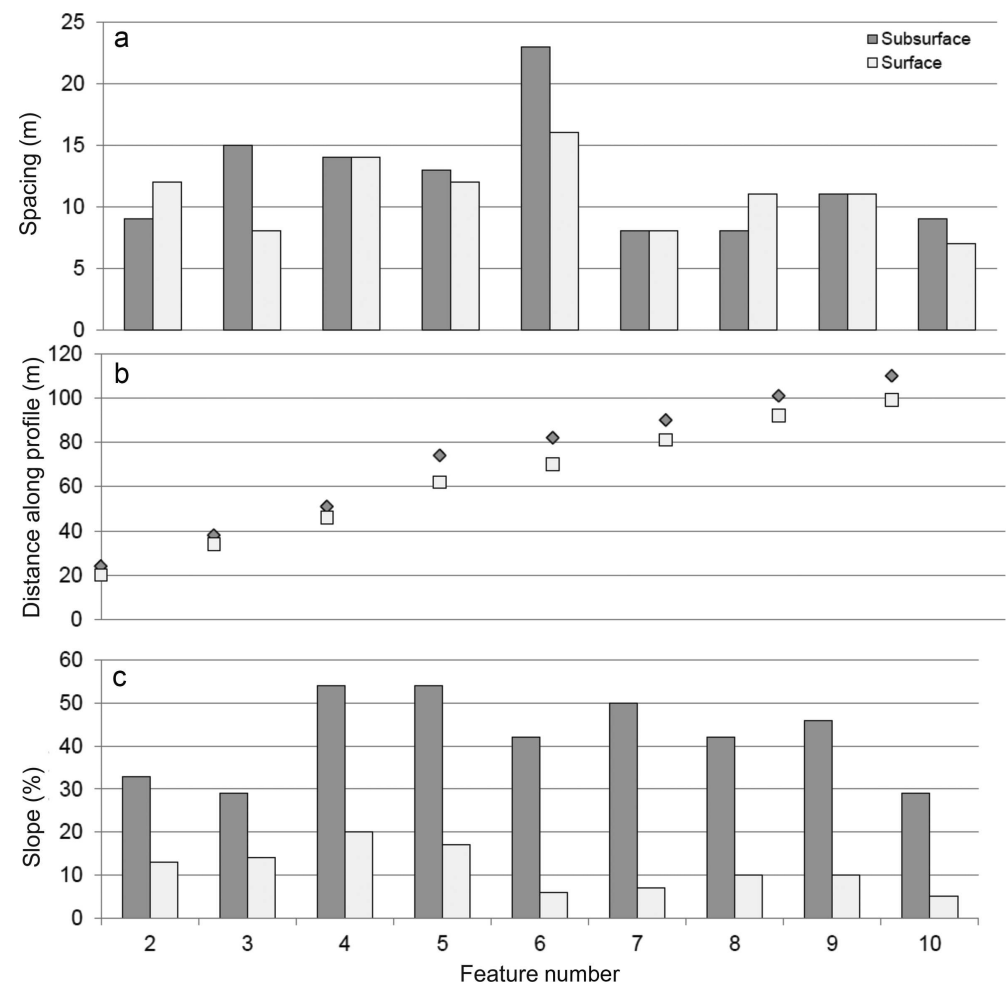

Fig. 6. (a) Spacing, (b) distance along longitudinal profile and (c) slope of surface and subsurface features 2-10.

is common at the edge of mountain cirques (Wahrhaftig and Cox, 1959; Kääb and others, 1998; Leonard and others, 2005). The cirque topography at LPRG suggests just such a flattening of terrain.

The geometries represented in both surface and subsurface transverse profile data appear to be the result of interaction between fault planes. The transverse $100 \mathrm{MHz}$ GPR profile suggests a synclinal bowl structure (Fig. 4d) that is similar to the structures observed in transverse sections of Arctic rock glaciers (Fukui and others, 2007, 2008). These structures also occur in glacial settings with longitudinal flow and transverse compression (Elconin and LaChapelle, 1997). However, transverse compression does not seem to be the explanation for the LPRG features, since the rock glacier is not connected with lateral cirque walls (Fig. 1b). The synclinal structures detected in the $100 \mathrm{MHz}$ GPR radargram are interpreted to be the transverse expression of upslope-dipping reflectors detected in the longitudinal dimension. If we assume that the rock glacier is moving fastest in the center, the cross-sectional geometry of these transverse reflectors is consistent with the arcuate nature of transverse ridges in plan view.

The spacing of surface and subsurface features is similar (Figs 5 and 6). Figure 5 shows annotated topographic (Fig. 5a), seismic (Fig. 5b) and $100 \mathrm{MHz}$ GPR (Fig. 5c) data, where 14 individual ridges are identified (Fig. 5a-c). Upslope-dipping reflectors in the subsurface $100 \mathrm{MHz}$ GPR data are much more closely spaced toward the toe of the rock glacier such that individual features are difficult to identify. Coincidentally, topography at the surface becomes less prominently ridge-like, making individual features difficult to identify at the surface as well. Features 2-10 are presented in detrended surface topography and $100 \mathrm{MHz}$ GPR data in Figure 5, where the spatial relationship between transverse ridges at the surface and reflectors interpreted to be thrust faults in the subsurface is apparent.

\section{Heterogeneity of ice/debris and glaciotectonically altered sediment}

Applying seismic velocities for glacial debris $\left(V_{\text {debris }}=\right.$ $2000 \mathrm{~m} \mathrm{~s}^{-1}$; Sheriff and Geldart, 1995), temperate ice $\left(V_{\text {ice }}=3750 \mathrm{~m} \mathrm{~s}^{-1}\right.$; Röthlisberger, 1972) and the ice/rock mixture $\left(V_{\text {mixture }}=3500 \mathrm{~m} \mathrm{~s}^{-1}\right.$; measured at LPRG), we apply Wyllie's time average equation for porous materials to determine percent debris of the ice body at LPRG (Wyllie and others, 1958):

$$
V_{\text {mixture }}=\%_{\text {debris }} V_{\text {debris }}+\left(1-\%_{\text {debris }}\right) V_{\text {ice }}
$$

or

$$
\%_{\text {debris }}=\left(V_{\text {mixture }}-V_{\text {ice }}\right) /\left(V_{\text {debris }}-V_{\text {ice }}\right)
$$

This results in a percent debris value $\left(V_{\text {debris }}\right)$ of $14 \%$ and a percent ice value $\left(V_{\text {ice }}\right)$ of $86 \%$. However, when using the same measured value for longitudinal seismic wave velocity $\left(V_{\mathrm{p}}=3500 \mathrm{~m} \mathrm{~s}^{-1}\right.$; measured at LPRG) in Müller's (1943) empirically derived equation for permafrost ice bodies (Croce and Milana, 2002),

$$
P=\left(1 / V_{\mathrm{p}}-1 / 6250\right) /(1 / 2500-1 / 6250),
$$

a debris concentration of $\sim 45 \%$ and ice concentration $(P)$ of $\sim 55 \%$ results. Both methods indicate that LPRG is likely to contain a considerable proportion of ice, ranging from $55 \%$ to $86 \%$.

Transverse ridges, both at LPRG and other rock glaciers, seem to be associated with heterogeneous internal composition. We are unable to determine that heterogeneous composition is necessary to develop transverse ridges; however, transverse ridges have been observed for numerous rock glaciers where heterogeneous composition is present (Table 1). Analogue experiments that model rock glacier internal deformation using Xanthan gum, sand and gravel have shown that transverse ridges are more likely to develop when heterogeneous materials are present (Kääb and Weber, 
Table 1. Summary of selected studies on rock glacier internal composition, structure and transverse ridges

\begin{tabular}{|c|c|c|c|c|c|}
\hline Citation & Rock glacier site & Method & Debris-rich layers & $\begin{array}{l}\text { Upslope-dipping } \\
\text { debris-rich layers }\end{array}$ & $\begin{array}{l}\text { Transverse } \\
\quad \text { ridges }\end{array}$ \\
\hline Loewenherz and others (1989) & Mathematical model & $\begin{array}{l}\text { Linear stability analysis; instability } \\
\text { wavelength analysis }\end{array}$ & Yes & $\mathrm{n} / \mathrm{a}$ & Yes \\
\hline Arenson and others (2002) & Swiss Alps & Borehole drilling & Yes & $\mathrm{n} / \mathrm{a}$ & Yes \\
\hline Guglielmin and others (2004) & Italian Alps & Borehole drilling & Yes & $\mathrm{n} / \mathrm{a}$ & No \\
\hline Kääb and Weber (2004) & Experimental model & $\begin{array}{l}\text { Composite sand, gravel and Xanthan gum } \\
\text { fluids modeled flowing over } 30^{\circ} \text { ramp }\end{array}$ & Yes & $\mathrm{n} / \mathrm{a}$ & Yes \\
\hline Hausmann and others (2007) & Austrian Alps & Geophysical* & Yes & $\mathrm{n} / \mathrm{a}$ & Yes \\
\hline Fukui and others $(2007,2008)$ & Antarctica & GPR & Yes & Yes & Yes \\
\hline Shean and Marchant (2010) & Antarctica & GPR & Yes & Yes & Yes \\
\hline Monnier and others (2011) & French Alps & GPR & Yes & Yes & Yes \\
\hline This study & Northern Rockies & Geophysical, excavation, borehole & Yes & Yes & Yes \\
\hline
\end{tabular}

*Geophysical methods included GPR, gravimetric and seismic surveys.

2004). Materials with heterogeneous viscosity and density yielded strong folding, while homogeneous materials yielded either no or slight folding (Kääb and Weber, 2004). Other model-derived data indicate that shearing occurs in ice-rich layers, while debris-rich layers respond to comparable stresses via brittle deformation (Moore and others, 2010).

The interpretation of subsurface features as thrust planes does not require thrusting throughout the rock glacier ice body (e.g. thrusting wherein debris layers are sourced from the glacier bed). The presence of englacial debris-rich layers could be due to original glacier stratigraphy, which has been buried and altered at depth. The upslope-dipping reflectors at LPRG, interpreted as thrust faults, are closer together and almost indistinguishable toward the toe (Fig. 5c). Similar imbricate thrust faulting has been observed in glaciotectonically altered and glacially entrained sediment (Bennett and others, 1996, 1999; Pyke and others, 2002; Murray and Booth, 2010). Thrust faulting within glaciotectonically altered sediment observed at the Kongsvegen/ Kronebreen tidewater glacier complex in Svalbard is described in detail by Bennett and others (1996, 1999). Englacial thrusts are steeper $\left(25-40^{\circ}\right)$ than proglacial thrusts $\left(15-30^{\circ}\right)$ observed in a thrust-moraine system on Ossian Sarsfjellet (Bennett and others, 1996, 1999). Similarly, the subsurface structures at LPRG interpreted as englacial thrusts range from $12^{\circ}$ to $28^{\circ}$, and are steeper than the surface expression of these thrusts $\left(2-11^{\circ}\right)$ (Fig. 6).

Glaciotectonically altered sediment at Matanuska Glacier, Alaska, demonstrates thick-skinned-style glaciotectonics, where an ice-cored moraine complex buried in overlying unconsolidated sediment deforms due to the readvance of active ice (Pyke and others, 2002). Overlying unconsolidated sediment is affected by the deformation of the ice-cored moraine complex beneath it, resulting in thrust features at the surface (Pyke and others, 2002). This is similar to the way in which the unconsolidated talus mantle at LPRG is affected by the deformation of the frozen ice core beneath.

\section{Stress and strain rate}

Stress and strain-rate analysis would improve our understanding of deformation mechanics within complex rock glacier ice bodies. However, with the limited data to hand we can only outline first-order approximations for basal shear stress and strain rate at LPRG. There are inherent caveats to such calculations, the major one being that the calculations are for the entire rock glacier body rather than discrete layers within it. Given these caveats, we proceed by considering basal shear stress $(\sigma)$ as defined by

$$
\sigma=\rho g h \sin \alpha
$$

and density derived from our seismic data, yielding

$$
\rho=\left(0.55 \rho_{\text {ice }}\right)+\left(0.45 \rho_{\text {debris }}\right)
$$

where the density of ice $\left(\rho_{\text {ice }}\right)$ is $967 \mathrm{~kg} \mathrm{~m}^{-3}$ and the density of debris $\left(\rho_{\text {debris }}\right)$ is $2700 \mathrm{~kg} \mathrm{~m}^{-3}$. Surface slope $(\alpha)$ is approximated based on measurements taken in the field $\left(\sim 10^{\circ}\right)$, and height is based on maximum penetration depth of $25 \mathrm{MHz}$ GPR data $(60 \mathrm{~m})$. The above calculation of density $(\rho)$ yields $1747 \mathrm{~kg} \mathrm{~m}^{-3}$. Using these data and $g=9.8 \mathrm{~m} \mathrm{~s}^{-2}$, the calculated value for basal shear stress $(\sigma)$ at LPRG is $179 \mathrm{kPa}$. The same calculation using our alternative density estimate $(86 \%$ ice, $14 \%$ debris; Wyllie and others, 1958) yields $\sigma=124 \mathrm{kPa}$. We re-emphasize that we are estimating the density of the ice/rock mixture and rock glacier thickness based on seismic refraction and GPR results.

We can approximate strain rate by considering the kinematics of the rock glacier body

$$
(\mathrm{d} y / \mathrm{d} x) / \mathrm{d} t=(\mathrm{d} x / \mathrm{d} t) / \mathrm{d} y
$$

where $(\mathrm{d} y / \mathrm{d} x) / \mathrm{d} t$ is strain rate, $\mathrm{d} x / \mathrm{d} t=0.2 \mathrm{ma}^{-1}$ is an approximate velocity and $\mathrm{d} y=60 \mathrm{~m}$ is approximate thickness. The resulting strain-rate estimate for LPRG is $10^{-10} \mathrm{~s}^{-1}$. The range of basal shear stress $(124-179 \mathrm{kPa})$ and our approximate strain-rate $\left(10^{-10} \mathrm{~s}^{-1}\right)$ calculations are consistent with experimental results from studies on rock glacier ice response to triaxial stress conditions, where stress tests in the range 124-179 kPa yielded strain rates of $\sim 10^{-9} \mathrm{~s}^{-1}$ (Arenson and Springman, 2005), and primary creep strain rates of $10^{-7}-10^{-11} \mathrm{~s}^{-1}$ for rock glacier pressuremeter tests in situ (Arenson and others, 2003).

\section{CONCLUSIONS}

Whereas well-established mass-balance and deformation models exist for traditional alpine glaciers, rock glacier mechanics, including mass balance and deformation, remain uncertain. Commonly occurring transverse ridges on rock glaciers are potential geomorphic indicators of internal deformation. This study has demonstrated the spatial relationship of surface and subsurface structures at LPRG. 
Based on analysis of the data, we determined endogenous processes are likely responsible for the observed surface and subsurface features.

\section{ACKNOWLEDGEMENTS}

Financial support for this research was provided by the Big Sky Institute, Big Sky Resort, the Swenson family and Montana State University Undergraduate Scholar Program. Dave Lageson and Christina Carr aided in the initial interpretation of GPR data and possible structural analogs. Cathy Whitlock provided editorial guidance. Thanks to Big Sky Resort, especially Mike Unruh and Taylor Middleton, for facilitating field research, Lindsey Brown, Tim Brox, Jennifer Giskaas, Blaine Kaphammer, Katie Monaco, Scott Montross, David Sunwall and Brian Williams for field assistance, and Teejet Corporation, particularly Corey Colliver, for help with GPS data collection. The lidar source used for preparing images in the figures was the US National Center for Airborne Laser Mapping, sponsored by the National Science Foundation, http://calm.geo.berkeley.edu/ncalm/ddc.html, accessed December 2011. Funding from the Montana Institute on Ecosystems, the Big Sky Rock Glacier Fund supported by Robert Swenson and Taylor Middleton, and NSF EPSCoR Track 1 grant (EPS-1101342) are gratefully acknowledged.

\section{REFERENCES}

Arenson LU and Springman SM (2005) Triaxial constant stress and constant strain rate tests on ice-rich permafrost samples. Can. Geotech. J., 42(2), 412-430 (doi: 10.1139/t04-111)

Arenson LU, Hoelzle M and Springman S (2002) Borehole deformation measurements and internal structure of some rock glaciers in Switzerland. Permafrost Periglac. Process., 13(2), 117-135 (doi: 10.1002/ppp.414)

Arenson LU, Springman SM and Hawkins PG (2003) Pressuremeter tests within an active rock glacier in the Swiss Alps. In Phillips M, Springman SM and Arenson LU eds. Permafrost: Proceedings of the 8th International Conference on Permafrost. Balkema, Lisse, 33-38

Barsch D (1996) Rockglaciers: indicators for the present and former geoecology in high mountain environments. (Springer Series in Physical Environment 16) Springer, Berlin

Bennett MR, Hambrey MJ, Huddart D and Ghienne JF (1996) The formation of a geometrical ridge network by the surge-type glacier Kongsvegen, Svalbard. J. Quat. Sci., 11(6), 437-449 (doi: 10.1002/(SICI)1099-1417(199611/12)11:6<437::AID JQS269>3.0.CO;2-J)

Bennett MR, Hambrey MJ, Huddart D, Glasser NF and Crawford KR (1999) The landform and sediment assemblage produced by a tidewater glacier surge in Kongsfjorden, Svalbard. Quat. Sci. Rev., 18(10-11), 1213-1246 (doi: 10.1016/S0277-3791(98)90041-5)

Berthling I, Etzelmüller B, Isaksen K and Sollid JL (2000) Rock glaciers on Prins Karls Forland. II: GPR soundings and the development of internal structures. Permafrost Periglac. Process., 11(4), 357-369 (doi: 10.1002/1099-1530(200012) 11:4<357::AID-PPP366>3.0.CO;2-6)

Clark DH, Clark MM and Gillespie AR (1994) Debris-covered glaciers in the Sierra Nevada, California, and their implications for snowline reconstructions. Quat. Res., 41(2), 139-153 (doi: 10.1006/qres.1994.1016)

Croce FA and Milana JP (2002) Internal structure and behaviour of a rock glacier in the arid Andes of Argentina. Permafrost Periglac. Process., 13(4), 289-299 (doi: 10.1002/ppp.431)

Degenhardt JJ (2009) Development of tongue-shaped and multilobate rock glaciers in alpine environments - interpretations from ground penetrating radar surveys. Geomorphology, 109(34), 94-107 (doi: 10.1016/j.geomorph.2009.02.020)
Degenhardt JJ and Giardino JR (2003) Subsurface investigation of a rock glacier using ground-penetrating radar: implications for locating stored water on Mars. J. Geophys. Res., 108(E4), 8036 (doi: 10.1029/2002JE001888)

Elconin RF and LaChapelle ER (1997) Flow and internal structure of a rock glacier. J. Glaciol., 43(144), 238-244

Florentine CE (2011) Regional context, internal structure, and microbiological investigation of the Lone Peak Rock Glacier, Big Sky, Montana. (MS thesis, Montana State University)

Fukui K, Sone T, Strelin J, Torielli C and Mori J (2007) Groundpenetrating radar sounding on an active rock glacier on James Ross Island, Antarctic Peninsula region. Pol. Polar Res., 28(1), $13-22$

Fukui K, Sone T, Strelin JA, Torielli CA, Mori J and Fujii Y (2008) Dynamics and GPR stratigraphy of a polar rock glacier on James Ross Island, Antarctic Peninsula. J. Glaciol., 54(186), 445-451 (doi: 10.3189/002214308785836940)

Goolsby JE (1972) East Rock Glacier of Lone Mountain, Madison County, Montana. (MS thesis, Montana State University)

Guglielmin M, Camusso M, Polesello S and Valsecchi S (2004) An old relict glacier body preserved in permafrost environment: the Foscagno rock glacier ice core (Upper Valtellina, Italian Central Alps). Arct. Antarct. Alp. Res., 36(1), 108-116

Haeberli W (1985) Creep of mountain permafrost: internal structure and flow of Alpine rock glaciers. Mitt. VAW/ETH 77

Haeberli W and 10 others (2006) Permafrost creep and rock glacier dynamics. Permafrost Periglac. Process., 17(3), 189-214 (doi: 10.1002/ppp.561)

Hamilton SJ and Whalley WB (1995) Rock glacier nomenclature: a re-assessment. Geomorphology, 14(1), 73-80 (doi: 10.1016/ 0169-555X(95)00036-5)

Hausmann H, Krainer K, Brückl E and Mostler W (2007) Internal structure and ice content of Reichenkar rock glacier (Stubai Alps, Austria) assessed by geophysical investigations. Permafrost Periglac. Process., 18(4), 351-367 (doi: 10.1002/ppp.601)

Ikeda A, Matsuoka N and Kääb A (2008) Fast deformation of perennially frozen debris in a warm rock glacier in the Swiss Alps: an effect of liquid water. J. Geophys. Res., 113(F1), F01021 (doi: 10.1029/2007JF000859)

Isaksen K, Ødegård RS, Eiken T and Sollid JL (2000) Composition, flow and development of two tongue-shaped rock glaciers in the permafrost of Svalbard. Permafrost Periglac. Process., 11(3), 241-257 (doi: 10.1002/1099-1530(200007/09)11:3<241::AIDPPP358>3.0.CO;2-A)

Iverson NR and 6 others (2003) Effects of basal debris on glacier flow. Science, 301(5629), 81-84 (doi: 10.1126/science.1083086)

Jakobsen PR and Overgaard T (2002) Georadar facies and glaciotectonic structures in ice marginal deposits, northwest Zealand, Denmark. Quat. Sci. Rev., 21(8-9), 917-927 (doi: 10.1016/S0277-3791(01)00045-2)

Johnson BG, Thackray GD and Van Kirk R (2007) The effect of topography, latitude, and lithology on rock glacier distribution in the Lemhi Range, central Idaho, USA. Geomorphology, 91(1-2), 38-50 (doi: 10.1016/j.geomorph.2007.01.023)

Kääb A and Weber M (2004) Development of transverse ridges on rock glaciers: field measurements and laboratory experiments. Permafrost Periglac. Process., 15(4), 379-391 (doi: 10.1002/ ppp.506)

Kääb A, Gudmundsson GH and Hoelzle M (1998) Surface deformation of creeping mountain permafrost. Photogrammetric investigations on rock glacier Murtèl, Swiss Alps. In Lewkowicz AG and Allard $\mathrm{M}$ eds. Proceedings of the 7th International Permafrost Conference, 23-27 June 1998, Yellowknife, N.W.T., Canada. (Collection Nordicana, Centre d'Études Nordiques, Université Laval 57) Canadian National Committee for the International Permafrost Association, 531-537

Konrad SK, Humphrey NF, Steig EJ, Clark DH, Potter N Jr and Pfeffer WT (1999) Rock glacier dynamics and paleoclimatic implications. Geology, 27(12), 1131-1134 (doi: 10.1130/00917613(1999)027<1131:RGDAPI >2.3.CO;2) 
Lawson W and Elliott C (2003) Strain-rate effects on the strength of debris-laden glacier ice. New Zeal. J. Geol. Geophys., 46(3), 323-330 (doi: 10.1080/00288306.2003.9515012)

Leonard EM, Staab P and Weaver SG (2005) Kinematics of Spruce Creek rock glacier, Colorado, USA. J. Glaciol., 51(173), 259-268 (doi: 10.3189/172756505781829403)

Leopold M, Dethier D, Völkel J, Raab T, Corson Rikert T and Caine N (2008) Using geophysical methods to study the shallow subsurface of a sensitive Alpine environment, Niwot Ridge, Colorado Front Range, USA. Arct. Antarct. Alp. Res., 40(3), 519-530

Locke WW (1990) Late Pleistocene glaciers and climate of western Montana, U.S.A. Arct. Alp. Res., 22(1), 1-13

Loewenherz DS, Lawrence CJ and Weaver RL (1989) On the development of transverse ridges on rock glaciers. J. Glaciol., 35(121), 383-391

Monnier S, Camerlynck C, Fejiba F, Kinnard C, Feuillet T and Dhemaied A (2011) Structure and genesis of the Thabor rock glacier (Northern French Alps) determined from morphological and ground-penetrating radar surveys. Geomorphology, 134(3-4), 269-279 (doi: 10.1016/j.geomorph.2011.07.004)

Moore PL, Iverson NR and Cohen D (2010) Conditions for thrust faulting in a glacier. J. Geophys. Res., 115(F2), F02005 (doi: 10.1029/2009JF001307)

Müller, SW (1943) Permafrost or permanently frozen ground and related engineering problems. US Engineers Office, Strategic Engineering Study, Special Report No. 62 (Reprinted in 1947, JW Edwards, Ann Arbor, MI)

Murray T and Booth AD (2010) Imaging glacial sediment inclusions in 3-D using ground-penetrating radar at Kongsvegen, Svalbard. J. Quat. Sci., 25(5), 754-761 (doi: 10.1002/jqs.1351)

Olyphant GA (1987) Rock glacier response to abrupt changes in talus production. In Giardino JR, Shroder JF, Jr and Vitek JD eds. Rock glaciers. Allen and Unwin, London, 55-64

Potter N Jr (1972) Ice-cored rock glacier, Galena Creek, northern Absaroka Mountains, Wyoming. Geol. Soc. Am. Bull., 83(10), 3025-3057 (doi: 10.1130/0016-7606(1972)83[3025:IRGGCN] 2.0.CO;2)

Potter N Jr, Steig EJ, Clark DH, Speece MA, Clark GM and Updike AB (1998) Galena Creek rock glacier revisited - new observations on an old controversy. Geogr. Ann. A, 80(3-4), 251-265 (doi: 10.1111/j.0435-3676.1998.00041.x)

Pyke K and 6 others (2002) Ground-penetrating radar imaging of glaciotectonic sediment deformation in an ice-cored moraine generated by movement of the buried ice during a re-advance of the active ice, Matanuska Glacier, Alaska. [Abstr. C62A-0904] Eos, 83(47), Fall Meet. Suppl.
Röthlisberger H (1972) Seismic exploration in cold regions. CRREL Monogr. II-A2a

Sadura S, Martini IP, Endres AL and Wolf K (2006) Morphology and GPR stratigraphy of a frontal part of an end moraine of the Laurentide Ice Sheet: Paris Moraine near Guelph, ON, Canada. Geomorphology, 75(1-2), 212-225 (doi: 10.1016/j.geomorph.2005.01.014)

Seligman ZM (2009) Rock glacier distribution, activity and movement, northern Absaroka and Beartooth ranges, MT, USA. (MS thesis, University of Montana)

Shean DE and Marchant DR (2010) Seismic and GPR surveys of Mullins Glacier, McMurdo Dry Valleys, Antarctica: ice thickness, internal structure and implications for surface ridge formation. J. Glaciol., 56(195), 48-64 (doi: 10.3189/ $002214310791190901)$

Sheriff RE and Geldart LP (1995) Exploration seismology. Cambridge University Press, Cambridge

Steig EJ, Fitzpatrick JJ, Potter N Jr and Clark DH (1998) The geochemical record in rock glaciers. Geogr. Ann. A, 80(3-4), 277-286 (doi: 10.1111/j.0435-3676.1998.00043.x)

Wagner S (1992) Creep of Alpine permafrost investigated on the Murtèl rock glacier. Permafrost Periglac. Process., 3(2), 157-162 (doi: 10.1002/ppp.3430030214)

Wahrhaftig C and Cox A (1959) Rock glaciers in the Alaska Range. Geol. Soc. Am. Bull., 70(4), 383-436 (doi: 10.1130/0016-7606 (1959)70[383:RGITAR]2.0.CO;2)

Whalley WB and Azizi F (2003) Rock glaciers and protalus landforms: analogous forms and ice sources on Earth and Mars. J. Geophys. Res., 108(E4), 8032 (doi: 10.1029/2002JE001864)

White SE (1971) Rock glacier studies in the Colorado Front Range, 1961 to 1968. Arct. Alp. Res., 3(1), 43-64

White SE (1987) Differential movement across transverse ridges on Arapaho Rock Glacier, Colorado Front Range, USA. In Giardino JR, Shroder JF Jr and Vitek JD eds. Rock glaciers. Allen and Unwin, Winchester, MA, 145-149

Woodward J and Burke MJ (2007) Applications of groundpenetrating radar to glacial and frozen materials. J. Environ. Eng. Geophys., 12(1), 69-85 (doi: 10.2113/JEEG12.1.69)

Woodward J, Murray T, Clark RA and Stuart GW (2003) Glacier surge mechanisms inferred from ground-penetrating radar: Kongsvegen, Svalbard. J. Glaciol., 49(167), 473-480 (doi: 10.3189/172756503781830458)

Wyllie MRJ, Gregory AR and Gardner GHF (1958) An experimental investigation of factors affecting elastic wave velocities in porous media. Geophysics, 23(3), 459-493 (doi: 10.1190/ $1.1438493)$ 